\title{
Assessment of liver enzymes in saliva and serum of Iraqi patients with chronic periodontitis disease
}

\author{
Hussein SH. Ridha Zahraa H.M. Kadri * \\ Department of medical lab technique /Al-Nisour University College \\ * Department of Biology / College of Education for Pure Science (Ibn Al-Haitham) / University of Baghdad
}

E-mail: Zahraaa_ali@yahoo.com

\begin{abstract}
Objective: The present study aimed to assess of four liver enzymes, Alanine Aminotransferase (ALT), Aspartate Transaminase (AST), Alkaline Phosphatase (ALP) and Gamma-Glutamyl Transpeptidase (GGT).

Material and Methods: Based on periodontal clinical parameters, sixty four patients with chronic periodontitis (CP) and twenty four controls were enrolled in the study. Saliva and serum samples were collected and Automated Chemistry Analyzer AU 480 was employed to assess levels of enzymes. Results: Compared to healthy controls, the levels of the four enzymes were significant increased in serum of patients, especially in the severe group while in the saliva a significant increase observed only in the level of AST. Moreover, Alanine Aminotransferase (ALT), Aspartate Transaminase (AST), Alkaline Phosphatase (ALP) and Gamma-Glutamyl Transpeptidase (GGT) the levels of these enzymes in serum were significantly higher than those in saliva.

Conclusion: ALT, AST, ALP and GGT serum levels are suggested to be important indicators for disease progression as well as predict the liver health.
\end{abstract}

Key words: Saliva, Serum, ALT, AST, ALP, GGT, Chronic periodontitis.

\section{Introduction}

Chronic Periodontitis Disease (CPD) is a chronic multi-factorial inflammation disease because contribution of genetic and environmental factors as well as age, living standards and systemic diseases to initiation and progression of disease $(1,2,3)$, which occurs in the supporting tissues of the tooth, that include gingiva, periodontal ligament, cementum and alveolar bone this is caused by the accumulation of bacterial groups on the surfaces of the teeth as well as between the teeth and thus will lead to side effects on the health gingiva due to the stimulation of the immune response against these bacterial assemblies that lead to damage and destroyed of gingival tissues and observed that the sensitivity of the host plays an important role in the initiation and development of chronic periodontitis $(4,5)$. CPD is diagnosed by several indicators which include the presence and extent of periodontal pockets, loss of clinical attachment, pattern and extent of alveolar bone loss, or a combination of these findings (6).

Saliva and serum are main sources for many biomarkers which effected by the host's immune responses in two positions local and systemic. In CPD the inflammation begins by releasing many of these biomarkers in responses to bacterial antigens such as chemical mediators and enzymes from infected gingival tissues and activation immune cells (polymorphonuclear and lymphocytes) (7), in addition the level of periodontal destruction depends on the balance between destructive and protective mediators (8), and the most periodontal related inflammatory mediators are IL-8, IL-1, TNF- $\alpha$, IP-10, MIP-1, MCP-1 and CTGF $(9,10,11)$, Also, activation of different enzymes reflected metabolic changes of the gingiva and teeth periodontium in inflammation such as Alanine Aminotransferase, Aspartate Transaminase, Alkaline Phosphatase, Gamma-Glutamyl Transpeptidase, acidic phosphatase, creatine kinase , lactate dehydrogenase and adenosine deaminase $(12,13,14)$. Therefore increase or decrease levels of these enzymes in saliva nor serum are a vital signs of periodontitis progression, as well as evaluation of therapy effects and guess the health state of liver in future $(15,16)$.

Accordingly, the present study was planned to evaluation of liver enzymes in saliva and serum in a sample of Iraqi patients and to compare if enzymes present in saliva could be a viable alternative biomarker for knowing the progress of the periodontal diseases. 


\section{Materials and Methods}

Subjects: sixty four Iraqi persons of both genders (32 males and 32 females) with CPD and 24 healthy persons (control) their age mean \pm S.E. was $(40.58 \pm 2.30)$ attending Specialized Health Center for Dental Medicine / Al-Kadhimiya /Baghdad during the period October 2017 - February 2018 were enrolled in this study. They were clinically examined and evaluated by the consultant medical staff at the Health Center. The patients were classified according to the clinical examination : probing pocket depth (PPD), clinical attachment level (CAL) and plaque index (PLI) into three clinical groups 30 mild their age mean \pm S.E. was $(40.53 \pm 2.33), 26$ moderate their age mean \pm S.E. was $(39.30 \pm 2.03)$ and 8 severe their age mean \pm S.E. was $(40.50 \pm 2.87)$ cases (17). Patient with a history of Smoking, chronic diseases or under any type of therapy and pregnant women were excluded from the study.

Serum and saliva samples: Venous blood was collected from participants and left for 15 minutes to clot at room temperature, and then it was centrifuged (3000 rpm for 15 minutes). Saliva samples were also collected under unstimulated conditions by spitting into a sterile universal tube and the samples were placed immediately on ice and before prior to freezing. The separated sera and collected saliva were frozen at $-80^{\circ} \mathrm{C}$ until assessment (18).

Methods: ALT, AST, ALP and GGT were determined in serum and saliva by means of Automated Chemistry Analyzer AU 480 using commercially available kits (Human ALT, AST, ALP and GGT; Beckman Coulter), and the instructions of statistically analyzed using SPSS (Statistical Package for Social Sciences) version 13. Data were presented in terms of mean \pm standard error (S.E.), and differences between means were assessed by ANOVA (Analysis of Variance), followed by LSD (Least Significant Difference) or Duncan test. The difference was considered significant when the manufacturer were followed.

Statistical Analysis: The results were probability $(\mathrm{P})$ value was $\leq 0.05$.

\section{Results and Discussion}

Liver is a very important immune organ as well as its importance in digestion processes. Therefore in this study we focused on effect of chronic periodontities on liver functions health by evaluating liver enzymes functions (ALT, AST, ALP and GGT) and compare between their levels in saliva and serum samples. As shown in Table 1, gradual increase was observed in the levels of ALT in saliva patients with chronic periodontitis its levels reached in mild $1.11 \pm 0.24 \mathrm{u} / \mathrm{l}$, moderate $1.19 \pm 0.33 \mathrm{u} / 1$ and severe $1.55 \pm 0.34 \mathrm{u} / 1$ compared to controls $0.69 \pm 0.20 \mathrm{u} / \mathrm{l}$. The results were in agreement with (19) and (20) studies which showed an increase in the level of ALT in saliva patients as a result of an immune response against the germicidal bacteria deposited in the gingiva and then this enzymes secrete by inflammatory and damage cells as well as the high level of this enzyme indicator for inflammation and gingival tissue destruction and its activity increase with progression inflammation due to metabolic changes that happen in gingival tissue and periodontium and the results showed that there was a significant increase in the level of ALT in serum patient especially in patients with severe chronic periodontitis, where it was $14.21 \pm 1.94 \mathrm{u} / 1$ compared to the other groups and to the controls $8.76 \pm 1.24 \mathrm{u} / 1$, this study agreed with $(21)$ that showed an enzyme increase due to metabolic changes in inflamed gingiva.

Table (1): ALT level in saliva and serum patients with periodontitis

\begin{tabular}{|c|c|c|c|c|}
\hline \multirow{2}{*}{\multicolumn{2}{|c|}{ Groups }} & \multicolumn{2}{|c|}{ ALT $($ Mean \pm SE; u/l) } & \multirow{2}{*}{$\begin{array}{c}\text { Probability } \\
\leq\end{array}$} \\
\hline & & Saliva & Serum & \\
\hline \multirow{3}{*}{$\begin{array}{c}\text { Chronic } \\
\text { periodontal } \\
\text { disease }\end{array}$} & Mild (No.=30) & $1.11 \pm 0.24^{a}$ & $8.77 \pm 0.66^{b}$ & 0.001 \\
\hline & Moderate $($ No. $=26)$ & $1.19 \pm 0.33^{a}$ & $10.33 \pm 0.94^{b}$ & 0.001 \\
\hline & Severe $($ No. $=8)$ & $1.55 \pm 0.34^{\mathrm{a}}$ & $14.21 \pm 1.94^{\mathrm{a}}$ & 0.001 \\
\hline \multicolumn{2}{|c|}{ Controls $($ No. $=24)$} & $0.69 \pm 0.20^{\mathrm{a}}$ & $8.76 \pm 1.24^{b}$ & 0.001 \\
\hline
\end{tabular}

*Different letters represent significant difference $(P \leq 0.05)$ between means in columns, while similar letters represent no significant difference $(P>0.05)$ between these means (Duncan test).

In addition the results in Table (2) showed a significant increase in the AST level in saliva patient with chronic periodontitis its level reached in mild to $7.04 \pm 0.84 \mathrm{u} / 1$, in moderate to $7.28 \pm 0.98 \mathrm{u} / 1$ and in severe to $9.54 \pm 1.36 \mathrm{u} / 1$ compared to control $2.95 \pm 0.69 \mathrm{u} / \mathrm{l}$, and its level increase too in serum patient with chronic periodontitis the high level show in severe chronic periodntitis group $23.97 \pm 3.39 \mathrm{u} / 1$ compared to control $16.10 \pm 0.94 \mathrm{u} / \mathrm{l}$. Several studies have shown an increase in the level of the enzyme in the saliva and serum of chronic periodontitis patients as a result of inflammation and destruction of cellular membranes that lead to increase in the secretion of the enzyme and became high levels in saliva, It was also found rise in the level of the enzyme due to the attraction neutrophils by chemokines that well secreted by infected tissue after stimulation this tissue during immune response so will neutrophils secrete this enzyme that stored in her 
vesicles and found a positive relationship between increased secretion of this enzyme with increased periodontal pocket depth $(22,23)$.

Table (2): AST level in saliva and serum patients with periodontitis

\begin{tabular}{|c|c|c|c|c|}
\hline \multirow{2}{*}{\multicolumn{2}{|c|}{ Groups }} & \multicolumn{2}{|c|}{ AST $($ Mean \pm SE; u/l) } & \multirow{2}{*}{$\begin{array}{c}\text { Probability } \\
\leq\end{array}$} \\
\hline & & Saliva & Serum & \\
\hline \multirow{3}{*}{$\begin{array}{c}\text { Chronic } \\
\text { periodontal } \\
\text { disease }\end{array}$} & Mild (No.=30) & $7.04 \pm 0.84^{a}$ & $17.21 \pm 0.67^{b}$ & 0.001 \\
\hline & Moderate (No.=26) & $7.28 \pm 0.98^{\mathrm{a}}$ & $19.38 \pm 0.87^{b}$ & 0.001 \\
\hline & Severe $($ No. $=8)$ & $9.54 \pm 1.36^{a}$ & $23.97 \pm 3.39^{a}$ & 0.001 \\
\hline \multicolumn{2}{|c|}{ Controls $($ No. $=24)$} & $2.95 \pm 0.69^{b}$ & $16.10 \pm 0.94^{b}$ & 0.001 \\
\hline
\end{tabular}

*Different letters represent significant difference $(P \leq 0.05)$ between means in columns, while similar letters represent no significant difference $(P>0.05)$ between these means (Duncan test).

The results of Table (3) showed no significant increase in the level of ALP in saliva patients with chronic periodontitis and in the three patients groups as compared to the controls. A study by researchers (24) revealed a high level of Alkaline phosphatase enzyme in saliva patients with autoimmune disease Rheumatoid Arthritis, The high level of the enzyme was also shown with increase the severity of the inflammation due to the destruction of the alveolar bone of the tooth, which is a source of the production of this enzyme and also as a result of the destruction of gingival tissue (25), furthermore, the study by (26) and (27) showed that the levels of enzyme in patient with chronic periodontitis was higher than that of gingivitis and also higher than that of healthy individuals and also found increase in the level of this enzyme due to secretion by the neutrophils vesicles that attraction by chemokines secreted from infected tissues (28) and increased levels of this enzyme were also shown with increased periodontal pocket depth in chronic periodontitis patients (29).

In addition, a statistically significant increase was found in the serum patients with chronic periodontitis as compared with healthy and its levels reached in mild to $53.18 \pm 1.63 \mathrm{u} / 1$, in moderate $58.03 \pm 3.68 \mathrm{u} / 1$ and in severe $59.12 \pm 3.79 \mathrm{u} / \mathrm{l}$ compared to the controls $42.82 \pm 3.12 \mathrm{u} / 1$, Several studies have confirmed a significant increase in the level of ALP in serum patient with chronic periodontitis, particularly with severe cases of inflammation $(30,31)$ due to its secretion by vesicles of neutrophil during its migration in the blood vessels to the site of injury as well as the destruction of alveolar bone (32).

Table (3): ALP level in saliva and serum patients with periodontitis

\begin{tabular}{|c|c|c|c|c|}
\hline \multirow{2}{*}{\multicolumn{2}{|c|}{ Groups }} & \multicolumn{2}{|c|}{ ALP $($ Mean \pm SE; u/l) } & \multirow{2}{*}{$\begin{array}{c}\text { Probability } \\
\leq\end{array}$} \\
\hline & & Saliva & Serum & \\
\hline \multirow{3}{*}{$\begin{array}{c}\text { Chronic } \\
\text { periodontal } \\
\text { disease }\end{array}$} & Mild $($ No.=30) & $2.21 \pm 0.37^{a}$ & $53.18 \pm 1.63^{a}$ & 0.001 \\
\hline & Moderate $($ No. $=26)$ & $2.33 \pm 0.24^{a}$ & $58.03 \pm 3.68^{a}$ & 0.001 \\
\hline & Severe $($ No. $=8)$ & $2.76 \pm 0.51^{\mathrm{a}}$ & $59.12 \pm 3.79^{a}$ & 0.001 \\
\hline \multicolumn{2}{|c|}{ Controls $($ No. $=24)$} & $1.57 \pm 0.34^{\mathrm{a}}$ & $42.82 \pm 3.12^{b}$ & 0.001 \\
\hline
\end{tabular}

*Different letters represent significant difference $(\mathrm{P} \leq \mathbf{0 . 0 5})$ between means in columns, while similar letters represent no significant difference $(P>0.05)$ between these means (Duncan test).

The results of Table (4) showed no significant increase in the level of GGT in saliva patient with chronic periodontitis compared to the control individuals. However, there was a significant gradual increase in the level of GGT in serum patient with chronic periodontitis and in the three disease groups, in the group of patients with mild inflammation was $20.33 \pm 1.48 \mathrm{u} / 1$ and in the group of patients with moderate inflammation $28.17 \pm 2.56 \mathrm{u} / 1$ and the group of patients with severe inflammation $28.71 \pm 3.55 \mathrm{u} / 1$ compared to control group $18.88 \pm 2.12 \mathrm{u} / 1$, The results of the present study are in agreement with the results of the studies of (33), (34) and (35) which showed that an increase in the level of GGT in serum patients with chronic periodontitis is due to the immune response causing the destruction of cells and gingival tissues as well as metabolic changes in inflamed gingiva.

Table (4): GGT level in saliva and serum patients with periodontitis

\begin{tabular}{|c|c|c|c|c|}
\hline \multirow{2}{*}{\multicolumn{2}{|c|}{ Groups }} & \multicolumn{2}{|c|}{ GGT (Mean \pm SE; u/l) } & \multirow{2}{*}{$\begin{array}{c}\text { Probability } \\
\leq\end{array}$} \\
\hline & & Saliva & Serum & \\
\hline \multirow{3}{*}{$\begin{array}{l}\text { Chronic } \\
\text { periodontal } \\
\text { disease }\end{array}$} & Mild (No.=30) & $4.94 \pm 0.45^{\mathrm{a}}$ & $20.33 \pm 1.48^{b}$ & 0.001 \\
\hline & Moderate $($ No. $=26)$ & $5.08 \pm 0.46^{a}$ & $28.17 \pm 2.56^{a}$ & 0.001 \\
\hline & Severe $($ No. $=8)$ & $4.57 \pm 0.07^{\mathrm{a}}$ & $28.71 \pm 3.55^{a}$ & 0.001 \\
\hline \multicolumn{2}{|c|}{ Controls $($ No. $=24)$} & $4.69 \pm 0.51^{a}$ & $18.88 \pm 2.12^{b}$ & 0.001 \\
\hline
\end{tabular}

*Different letters represent significant difference $(P \leq 0.05)$ between means in columns, while similar letters represent no significant difference $(P>0.05)$ between these means (Duncan test). 
The results also declared that the level of the four enzymes showed an evidence for increase in serum compared to saliva (Tables 1, 2, 3 and 4). In conclusion ALT, AST, ALP and GGT are important serum biomarkers that are related to CPD and increase in their levels is a good indicator of the severity of inflammation. Therefore, it is preferable to measure ALT, AST, ALP and GGT levels in serum (systemic produced) rather than in saliva (local produced). Serum therefore, can give a better evaluation of the inflammatory condition in gingiva that is associated with these markers.

\section{References}

1. Yoon N, Lee J, Yu B. Association between Vitamin D Level in Blood and Periodontitis in Korean Elderly. J. Dent. Hyg. Sci. (2017); (3): 233-241.

2. Maribel Frías-Muñoz M, Araujo-Espino R, Martínez-Aguilar VM, Alcalde TC, Aguilera-Galaviz LA, Gaitán-Fonseca C. Aggressive Periodontitis and its Multidisciplinary Focus: Review of the Literature. ODOVTOS-International Journal of Dental Sciences. (2017); (19-3):27-33.

3. AlJehani YA. Risk Factors of Periodontal Disease: Review of the Literature. International Journal of Dentistry. (2014); 2014:1-9.

4. Cochran DL. Inflammation and bone loss in periodontal disease. Journal of periodontology. (2008); 79(8S): 1569-1576.

5. Taba M Jr, Souza SL, Mariguela VC. Periodontal disease: a genetic perspective. Braz Oral Res. (2012); 26 Suppl 1:32-38.

6. Shaju Jacob P. Measuring periodontitis in population studies: a literature review. Rev Odonto Cienc. (2011); 26(4): 346-354.

7. Türkoğlu O, Barış N, Tervahartiala T, Şenarslan Ö, Sorsa T, Atilla G. Evaluation of systemic levels of neutrophilic enzymes in patients with hypertension and chronic periodontitis. Journal of periodontology. (2014); 85(7): 908-916.

8. Shaker ZF, Hashem BH. Study the role of proinflammatory and anti-inflammatory cytokines in Iraqi chronic periodontitis patients. Journal of baghdad college of dentistry. (2012); 24 (special issue 1): 164-169.

9. Gupta M, Chaturvedi R, Jain A. Role of monocyte chemoattractant protein-1 (MCP-1) as an immune-diagnostic biomarker in the pathogenesis of chronic periodontal disease. Cytokine. (2013); 61(3): 892-897.

10. Mize TW, Sundararaj KP, Leite RS, Huang Y. Increased and Correlated Expression of CTGF and TGF $\beta 1$ in Surgically Removed Periodontal Tissues with Chronic Periodontitis. J. Periodontal. Res. (2015); 50 (3): 315-319.

11. Ridha HSH, Kadri ZHM. Assessment of some immunological biomarkers in saliva and serum of Iraqi patients with chronic periodontitis disease. Pharm.Sci \& Res. (2018); 11: 2998-3000.

12. Nomura Y, Shimada Y, Hanada N, Numabe Y, Kamoi K, Sato T, Gomi K, Arai T, Inagaki K, Fukuda M, Noguchi T. Salivary biomarkers for predicting the progression of chronic periodontitis. Archives of oral biology. (2012); 57(4): 413-420.

13. Koss MA, Castro CE, Salúm KM, López ME. Enzymatic profile of gingival crevicular fluid in association with periodontal status. Laboratory Medicine. (2009); 40(5): 277-280.

14. Khalil HM, Kadri ZHM, Rahman HK. Assessment of Adenosine deaminase specific activity in serum and saliva of patients with chronic gingivitis. Journal of Biotechnology Research Center (Special edition). (2014); 2: 37-40.

15. Zhang Z, Lin H, Shi M, Xu R, Fu J, Lv J, Chen L, Lv S, Li Y, Yu S, Geng H. Human umbilical cord mesenchymal stem cells improve liver function and ascites in decompensated liver cirrhosis patients. Journal of gastroenterology and hepatology. (2012); 27(s2): 112-120.

16. Nathwani RA, Pais S, Reynolds TB, Kaplowitz N. Serum alanine aminotransferase in skeletal muscle diseases. Hepatology. (2005); 41(2): 380-382.

17. Kinane DF. Periodontal diagnostics. Annals of the Royal Australasian College of Dental Surgeons. (2000); 15: 34-41.

18. Almerich-Silla JM, Pastor S, Serrano F, Puig-Silla M, Dasí F. Oxidative stress parameters in saliva and its association with periodontal disease and types of bacteria. Disease markers. (2015).

19. Dabra S, China K, Kaushik A. Salivary enzymes as diagnostic markers for detection of gingival/periodontal disease and their correlation with the severity of the disease. Journal of Indian society of periodontology. (2012); 16(3): 358.

20. Luke R, Khan SN, Iqbal PS, Soman RR, Chakkarayan J, Krishnan V. Estimation of specific salivary enzymatic biomarkers in individuals with gingivitis and chronic Periodontitis: a clinical and biochemical study. Journal of international oral health: JIOH. (2015); 7(9): 54. 
21. Wiener RC, Sambamoorthi U, Jurevic RJ. Association of Alanine Aminotransferase and Periodontitis: A Cross-Sectional Analysis-NHANES 2009-2012. International journal of inflammation. (2016).

22. Skrypnykov P, Nepokupna-Slobodyanyuk T, Shynkevich V. Levels of alanine-and aspartate aminotransferases in periodontal pockets in outcomes of chronic periodontitis therapy with azithromycin. Проблемы экологии и медицины. (2013); 17: 5-6.

23. Siddique S, Panchmal GS, Pullishery F. Aspartate aminotransferase as a biomarker in periodontal disease: A comparative in vitro study. Saudi Journal of Oral Sciences. (2016); 3(1): 21.

24. Deepika V, Priya VV, Bedre A, Harsha L. Salivary AST, ALP and CK Levels in Patients with Periodontitis. Journal of Pharmaceutical Sciences and Research. (2015); 7(6): 341.

25. Yoshie H, Tai H, Kobayashi T, Oda-Gou E, Nomura Y, Numabe Y, Ito K, Kurihara H, Kamoi K. Salivary enzyme levels after scaling and interleukin-1 genotypes in Japanese patients with chronic periodontitis. Journal of periodontology. (2007); 78(3): 498-503.

26. Daltaban Ö, Saygun I, Bal B, Baloş K, Serdar M. Gingival crevicular fluid alkaline phosphatase levels in postmenopausal women: Effects of phase I periodontal treatment. Journal of periodontology. (2006); 77(1): 67-72.

27. Patel RM, VaRMa S, SuRaGiMath G, ZoPe S. Estimation and comparison of salivary calcium, phosphorous, alkaline phosphatase and $\mathrm{pH}$ levels in periodontal health and disease: a crosssectional biochemical study. Journal of clinical and diagnostic research:JCDR. (2016); 10(7) :ZC58.

28. Agrawal N, Singhvi A, Upadhyay M, Kaur N, Yadav O, Khan M. Estimation of Serum Alkaline Phosphatase in Chronic Periodontitis in Smokers and Non-Smokers with Healthy Individuals: A Pilot Study. Int J Dent Med Res. (2014); 4(1): 30-34.

29. Malhotra R, Grover V, Kapoor A, Kapur R. Alkaline phosphatase as a periodontal disease marker. Indian Journal of Dental Research. (2010); 21(4): 531.

30. Gibert P, Tramini P, Sieso V, Piva MT. Alkaline phosphatase isozyme activity in serum from patients with chronic periodontitis. Journal of periodontal research. (2003); 38(4): 362-365.

31. Perumal GCL, Mythili R, Kumar S, Suyambukesan S. Serum total alkaline phosphatase enzyme level and severity of chronic periodontitis. International Journal of Current Research and Review. (2014); 6(17): 41-44.

32. Agrawal N, Singhvi A, Upadhyay M, Kaur N, Yadav O, Khan M. Estimation of Serum Alkaline Phosphatase in Chronic Periodontitis in Smokers and Non-Smokers with Healthy Individuals: A Pilot Study. Int. J. Dent. Med. Res. (2014); 4(1): 30-34.

33. Numabe Y, Hisano A, Kamoi K, Yoshie H, Ito K, Kurihara H. Analysis of saliva for periodontal diagnosis and monitoring. Dentistry in Japan. (2004); 40: 115-119.

34. Kishore PK, Yuvarajparmar SS. Evaluating the levels of salivary enzymes as biochemical markers in periodontal disease. International J. of Healthcare and Biomedical Research. (2014); 2(3): 170174.

35. Morita T, Yamazaki Y, Fujiharu C, Ishii T, Seto M, Nishinoue N, Sasaki Y, Kawato T, Motohashi M, Maeno M. Serum $\gamma$-glutamyltransferase level is associated with periodontal disease independent of drinking habits in Japanese adults. Medical science monitor: international medical journal of experimental and clinical research. (2014); 20: 2109. 